\title{
INFECCIÓN CON VIRUS DE PAPILOMA HUMANO
}

Por: Dr. Julio Mora Campos

Dra. Ana León Solano / Laboratorio Clínico UCIMED

\section{CLASIFICACIÓN DE GENOTIPOS DEL VPH}

a mayoría de las enfermedades de transmisión sexual tienen una estrecha relación con el comportamiento de los grupos poblacionales en este aspecto, mostrando relevancia algunos factores como:

\section{- Edad de inicio de la actividad sexual}

- Cambios frecuentes de parejas sexuales

- Múltiples parejas

\section{- Mala cultura de prevención}

El Virus del Papiloma Humano (VPH) son virus de ADN con doble banda pertenecientes a la familia Papovaviridae, la infección por este virus constituye la enfermedad más común de transmisión sexual (ETS) con un 10-20 \% de individuos jóvenes (15-49 años) sexualmente activos. Actualmente existen identificados aproximadamente 200 genotipos de VPH de los cuales 30 son responsables de infecciones ano genitales. Esta infección afecta mayormente órganos genitales recayendo la importancia del virus en su capacidad de causar verrugas y alrededor de los años sesentas el investigador Zur Hausen establece la relación existente entre este virus y el cáncer de cuello uterino.
Los tipos 16 y 18 son los genotipos más frecuentemente asociados al cáncer cervical, vulvar, de pene y anal. Los genotipos 6 y 11 se asocian al desarrollo de lesiones benignas como verrugas y condiloma acuminado.

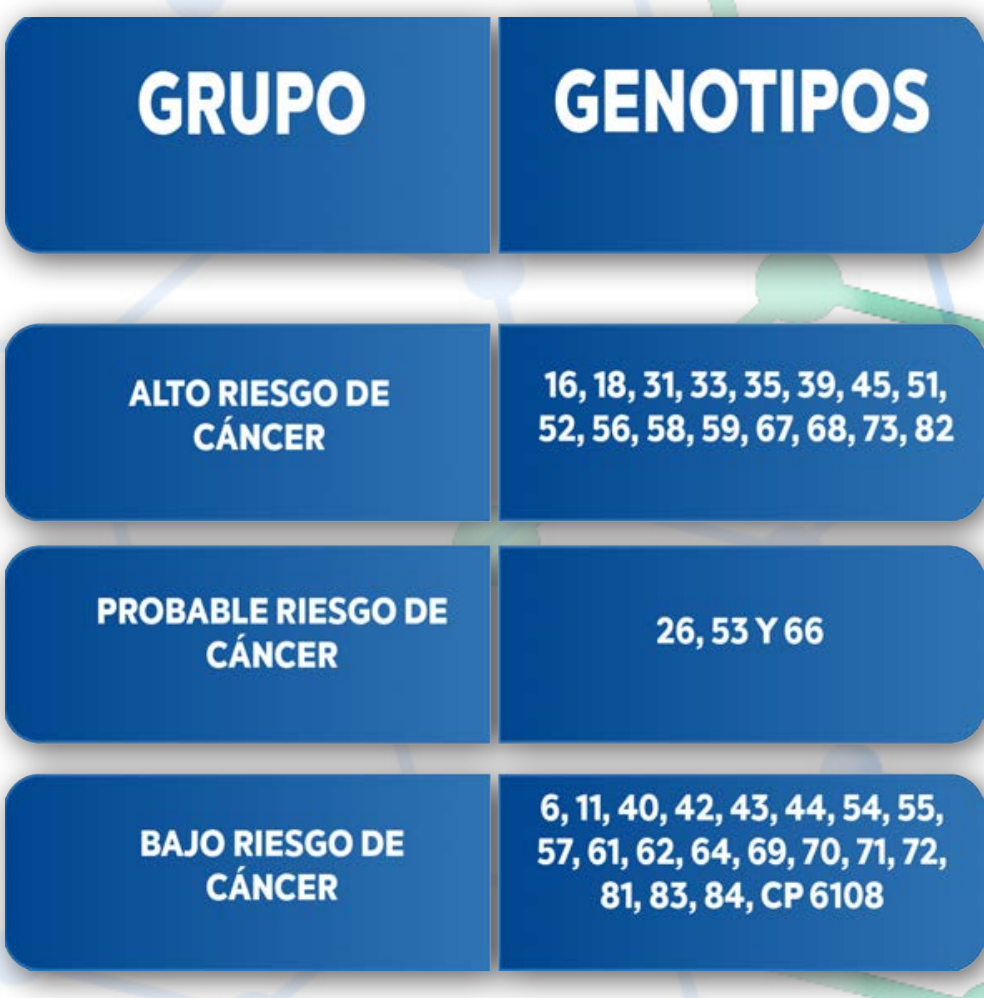

\section{DIAGNÓSTICO}

Se debe establecer un diagnóstico temprano para realizar un tratamiento inmediato. Debido a la falta de programas de prevención y detección específicos para la población masculina, estos cursan con infecciones por VPH de manera asintomática actuando como reservorios y contagiando a sus parejas.

Otro grupo evoluciona hacia verrugas genitales 


\begin{tabular}{|c|c|c|}
\hline GENOTIPO DE VPH & MANIFESTACIÓN CLINNICA & OBSERVACIÓN \\
\hline 6.,11 & $\begin{array}{l}\text { Papilomas nasal, oral, } \\
\text { laringe y anogenitales }\end{array}$ & $\begin{array}{l}\text { Probablemente } \\
\text { cancerígeno }\end{array}$ \\
\hline $26,53,66$ & Lesiones en mucosas & Virus de alto riesgo \\
\hline 5,8 & $\begin{array}{l}\text { Epidermodisplasia } \\
\text { verruciforme }\end{array}$ & $\begin{array}{l}\text { Enfermedad } \\
\text { dermatológica rara }\end{array}$ \\
\hline 1 & Verruga plantar & \\
\hline $4,26,27,29$ & Verrugas comunes & \\
\hline 16,18 & & $\begin{array}{l}\text { Relación causal } \\
\text { con cáncer anal }\end{array}$ \\
\hline
\end{tabular}

lesiones pre-neoplásicas y malignas del ano, pene, orofaringe y papilomatosis respiratoria recurrente.

\section{PRUEBA DE LABORATORIO}

El laboratorio utiliza varias pruebas que incluyen PCR sin embargo la técnica de hibridación (Blot Reverso) se cuenta entre las determinaciones rápidas de bajo costo y sensibles.

Determina 19 virus de Papiloma Humano anogenitales de medio y alto riesgo permitiendo la detección cualitativa de muestras de ADN procedentes de frotis o biopsia cervicouterinas, pene y ano.

Los virus detectados son : $16,18,26,31,33$, $35,39,45,51,52,53,56,58,59,66,68,69$, 73, y 82.

\section{PREVENCIÓN Y CONTROL}

Se basa en la educación y prevención de salud, la educación médica, los programas de detección, el diagnóstico y el tratamiento precoz, la notificación de las parejas sexuales, entre otras.

Los principales fines del control de las ETS son: evitar la infección y sus consecuencias, interrumpir la propagación y disminuir la cadena de contagio. Esto se logra con educación y promoción de salud, acompañadas de técnicas de sexo más seguro, una correcta vigilancia epidemiológica con programas de detección precoz, la notificación obligatoria, el diagnóstico y tratamiento precoces, al igual que el tratamiento de los contactos sexuales.

\section{Además de lo antes mencionado se deben incluir las $4 \mathrm{C}$}

- Consentimiento informado del paciente.

-Consejería: técnicas de prácticas sexuales seguras con menorriesgo (sexo sin penetración, uso de preservativos), información sobre ETS y sugerencia de realización de la prueba serológica anti VIH.

- Contactos: a través de entrevistas se conocen las conductas sexuales del paciente y sus contactos sexuales.

-Condones: correcto uso y evaluación de sus características (validez, envase en buen estado, cámara de aire, utilización de lubricantes acuosos, su uso durante toda la relación). 